\title{
STUDIES ON ASSIMILATION, MOBILIZATION, AND TRANSPORT OF LIPIDS BY THE FAT BODY AND HAEMOLYMPH OF PYRRHOCORIS APTERUS
}

\author{
JOAN STADLER MARTIN \\ Department of Zoology, University of Michigan, Ann Arbor, Michigan 48104
}

(Received 6 fanuary 1969; revised 21 April 1969)

\begin{abstract}
The incorporation and release of lipid in vitro by the fat body of adult female Pyrrhocoris apterus, and the lipid content and composition of the haemolymph were examined in relation to the cyclic growth and diminution of the fat body and the probable contribution of lipid from the fat body to the developing oöcytes. The fat body released lipid at a constant rate during most of the reproductive cycle and in non-reproducing (diapausing or ovariectomized) females. On the other hand, the rate at which the fat body incorporated lipid in vitro was markedly reduced during the period of major oöcyte growth (days 3-5 following the larval-adult ecdysis), while it remained high during the corresponding period after ovariectomy and was low in diapause. The change in rate of lipid incorporation appears to account for the change in the fat body from net accumulation of lipid (days 1-3) to net loss of lipid (during rapid oöcyte growth on days 3-5).

Several characteristics of lipid incorporation and mobilization in vitro by the Pyrrhocoris fat body are different from those of the few other insect species studied and from mammalian adipose tissues. In Pyrrhocoris, haemolymph or bovine serum albumin is required for the maximum rate of incorporation, which is ten times higher than that reported for other insects. The fat body of Pyrrhocoris is not dependent on an external source of glyceride-glycerol for the esterification of fatty acids. Lipid is released at a much slower rate than found in other insect species. The primary class of lipid released is triglyceride, the form in which lipid is stored in the fat body and which predominates among lipid classes in the haemolymph. The importance of the method used to label the fat body is discussed.

The haemolymph of adult female Pyrrhocoris is normally filled with lipid droplets and lipid-filled cells which closely resemble fat body cells. It is suggested that the release of lipid-filled cells from the fat body constitutes one phase of the mobilization of fat body lipid.
\end{abstract}

\section{INTRODUCTION}

Adult Pyrrhocoris apterus females normally lay their eggs in batches 5 days after the larval-adult ecdysis and every 3 to 4 days thereafter. Previous work has indicated that the ovary of $P$. apterus utilizes extraovarian lipid during yolk formation (MARTIN, 1969). The amount of lipid in the fat body more than doubles from days 1 to 3 after the larval-adult ecdysis and then decreases markedly during the following 2 days when the major growth of oöcytes occurs. The reduction in 
the lipid content of the fat body was shown to be functionally correlated with the accumulation of lipid by the growing ovaries. This paper examines the characteristics of lipid incorporation and mobilization by the fat body and the forms of lipid in the haemolymph, in order to elucidate how the fat body reverses the net movement of lipid from increase to decrease and to establish whether the processes involved are affected by the reproductive state of the female.

Lipid is transported in the haemolymph from the digestive tract to, among other organs, the fat body for transformation and storage, and from the fat body to other organs for utilization. The composition of lipid in the haemolymph is known for only a few species (Chino and GilberT, 1965; SRIDhara and Bhat, 1965; TieTz, 1967; BEENAKkers and GilBERT, 1968). Furthermore, the characteristics of the incorporation of lipid by the fat body have been studied in only one species (WLODAWER and LĄGWIŃSKA, 1967), while lipid release by the fat body has been examined in several species (TIETz, 1962, 1967; Chino and GrlberT, 1965; WlodaWER and BarańsKa, 1965; COOK and EdDington, 1967; BeENaKkERS and Gilbert, 1968; Bhakthan and Gilbert, 1968). On the basis of these studies and the present one, it appears that insects assimilate, transfer, and mobilize lipids in a variety of ways whose study has already become a subject of interest and importance to insect physiology.

\section{Insects and tissues}

\section{MATERIALS AND METHODS}

Adult female Pyrrhocoris apterus were used in this study. The procedure for rearing, maintenance, and surgery on these insects and for preparation of the fat body are described elsewhere (MarTin, 1969).

\section{Haemolymph lipids}

Pooled samples of haemolymph $(15 \mu \mathrm{l})$ were extracted in chloroform-methanol $(2: 1, \mathrm{v} / \mathrm{v})$ according to the method of Forch et al. (1957). The lipid classes (TG*, DG, MG, FFA, sterols, and steryl esters) were separated by TLC using a $250 \mu$ layer of silica gel-G (Warner-Chilcott Lab.) according to the procedure of Freeman and West (1966) as modified by MarTin (1969). Positions of the separated classes were visualized in reference lanes under u.v. light after staining with dichlorofluorescein. The amount of lipid in each class was measured by the dichromate procedure of AMENTA (1964) after calibration with trilinolein, diolein, monopalmitin, palmitic acid, cholesterol, and cholesteryl palmitate (see MarTIN, 1969). Phospholipids, which account for no more than $3 \cdot 1$ per cent of the total body lipid (MARTIN, 1969), were not measured in this study.

\section{Chemicals}

Palmitic acid-1-14 $\mathrm{C}(46.2 \mathrm{mc} / \mathrm{m}$-mole, 99 per cent radiochemical purity), linoleic acid-1 ${ }^{14} \mathrm{C}(37.8 \mathrm{mc} / \mathrm{m}$-mole, 98 per cent radiochemical purity), glyceryl

* Abbreviations: FFA, free fatty acid; MG, monoglyceride; DG, diglyceride; TG, triglyceride; BSA, bovine serum albumin; PPO, 2,5-diphenyloxazole; and POPOP, 1,4-bis-2(5-phenyloxazole)-benzene; TLC, thin-layer chromatography. 
tri(palmitate-1 $\left.{ }^{14} \mathrm{C}\right)(25.7 \mathrm{mc} / \mathrm{m}$-mole, 97 per cent radiochemical purity), and uniformly labelled D-glucose- ${ }^{14} \mathrm{C}$ ( $3 \mathrm{mc} / \mathrm{m}$-mole, 96 per cent radiochemical purity) were obtained from the Nuclear-Chicago Corporation. Inulin-carboxyl-14 $\mathrm{C}$ $(3.3 \mathrm{mc} / \mathrm{g})$ was obtained from the New England Nuclear Corporation. Labelled diglyceride was generously provided by Dr. W. E. M. Lands and was prepared in his laboratory from a lecithin in which oleate-1 ${ }^{14} \mathrm{C}$ was attached at the $\mathrm{C}-2$ position of the glycerol moiety (ROBERTSON and LANDS, 1962). It had a specific activity of approximately $68 \mathrm{mc} / \mathrm{m}$-mole. The fluors PPO and POPOP were obtained from Nuclear-Chicago Corporation and from Packard Instrument Company. Bovine serum albumin, fraction $\mathrm{V}$ powder, was obtained from Calbiochem (manufactured by Pentex). All other chemicals used were reagent grade.

\section{Measurement of radioactivity}

A Nuclear-Chicago Model 6850 'Unilux' ambient temperature liquid scintillation counter was used, together with low-potassium vials. Counting efficiency for ${ }^{14} \mathrm{C}$ was 85 per cent. Lipids and lipid extracts were counted in $0.3 \%$ PPO plus $0.01 \%$ POPOP in toluene; water-soluble samples were counted in Bray's solution (BRAY, 1960). Results were corrected for background and for quenching, which was measured by the channels ratio technique.

In order to ascertain the activity of the labelled substrate used in experiments on uptake and oxidation, paired aliquots of substrate were taken for counting when the labelled substrate was added to the incubation vessels.

\section{Lipid release in vitro}

A. Preparation of the labelled fat body. The lipid of the fat body was labelled by feeding the adults palmitate- $1{ }^{14} \mathrm{C}$ in the drinking water for several days. This procedure resulted in specific activities of 2000 to 4000 counts/min per $\mathrm{mg}$ dry wt. of fat body. The insects labelled in this way showed no apparent radiation damage as judged by behaviour, ovarian development, and morphology.

The labelled fat body was excised under cold Pyrrhocoris Ringer (MarTin, 1969), rinsed once, and a small piece of tissue was separated for measurement of specific activity. The uniformity of labelling in the fat body was examined by measuring the specific activity of extracted lipid in three regions of one labelled fat body; the results were $1800,1820,1990$ counts/min per mg dry wt. of tissues, showing reasonable homogeneity.

B. Measurement of lipid release. The excised labelled fat body was incubated in $500 \mu 1$ of Ringer at $25^{\circ} \mathrm{C}$ with a shaking rate of 76 oscillations $/ \mathrm{min}$. To measure the release of labelled lipid, aliquots of incubation medium $(100 \mu \mathrm{l})$ were taken at $5,15,30,45,60,90$, and $120 \mathrm{~min}$. When effects of additions to the medium were measured, the additions were made at $60 \mathrm{~min}$ and aliquots were taken every $15 \mathrm{~min}$ for the following $60 \mathrm{~min}$. Each aliquot was replaced immediately by $100 \mu \mathrm{l}$ of fresh incubation medium and was mixed with $0.5 \mathrm{ml}$ of isopropanolheptane-1 N sulphuric acid (40:10:1, v/v/v), according to the procedure of Dole 
(1956). Two extractions with heptane were sufficient to obtain more than 98 per cent of the activity.

Since the activity of each sample subsequent to the first was reduced by the removal of previous samples, the total amount of labelled lipid released between the start of incubation and time $t\left(R_{t}\right)$ was calculated by the relationship $R_{t+1}=$ $\left(x_{t+1} / y_{t}\right) R_{t}$, where $x_{i}$ is the activity measured in an aliquot taken at time $t$ and $y_{t}=4 / 5 x_{t}$. The derivation of this relationship is discussed in MARTIN (1968). The rate of release of labelled lipid $\Delta R / \Delta t$ was obtained from a least-squares regression calculated for $R_{t}$ as a function of $t$.

Since the diminutive size of the Pyrrhocoris fat body precluded obtaining accurate measurements of wet weight (owing to adhering fluid) and the loss of a few tiny pieces of tissue prevented retrieval of the entire tissue after incubation, the tissue dry weight was estimated on the basis of the mean dry weight of the fat body of that age or physiological condition (see MARTIN, 1969) minus the weight of the sample removed for measurement of specific activity.

C. Composition of labelled lipid in the fat body and released from the fat body. The composition of labelled lipid in the tissue and the medium was determined by separation on TLC (described above), and measurement of the radioactivity in each lipid class. Since no detectable amount of sterol or steryl ester was found in analysis of fat body (MARTIN, 1969) and haemolymph lipids, and since the present method does not separate phospholipid from other polar compounds, only FFA, MG, DG, and TG were examined. Cab-O-Sil (Packard Instrument Company) was added to the toluene fluor solution at a final concentration of $4 \%(\mathrm{w} / \mathrm{w})$ to suspend the silica gel, following the procedure of SNYDER and STEVENS (1962).

\section{Lipid uptake in vitro}

A. Uptake and esterification of fatty acid. Fat bodies were excised under cold Ringer and were incubated individually at $25^{\circ} \mathrm{C}$ and 120 oscillations/min. The routine incubation medium consisted of 0.31 to $0.50 \mathrm{~m} \mu$ moles $(25,000$ to 40,000 counts $/ \mathrm{min}$ ) of sodium palmitate- $1-{ }^{14} \mathrm{C}$ in $100 \mu \mathrm{l}$ of $5 \%(\mathrm{v} / \mathrm{v})$ adult Pyrrhocoris haemolymph in Pyrrhocoris Ringer. The proportion of labelled palmitate taken up was constant over the concentration range used.

After incubation, the fat body was vigorously rinsed twice, dried $20 \mathrm{hr}$ at $60^{\circ} \mathrm{C}$, weighed, and the lipids were extracted in ethanol-diethyl ether $(3: 1, \mathrm{v} / \mathrm{v})$. The solvent was removed and the neutral lipids were separated from the FFA in hexane-alcoholic sodium hydroxide $(3: 5, \mathrm{v} / \mathrm{v})$ according to the procedure of Borgström (1952). Control experiments showed that contamination of the neutral lipid fraction by FFA amounted to only 1.6 per cent of the total label.

B. Uptake of diglyceride and triglyceride. The lipid $(0.16$ to $0.93 \mathrm{~m} \mu$ moles, 7700 to 45,000 counts/min of TG, or 9 to 14 mumoles, 11,000 to 17,000 counts/min of $\mathrm{DG}$ ), dissolved in diethyl ether, was dispersed in the incubation medium, and the ether was removed under a stream of water-saturated nitrogen. Other procedures were identical with those employed in measuring FFA uptake. 


\section{Oxidation of labelled substrate to $\mathrm{CO}_{2}$}

Excised fat bodies were incubated individually in Warburg manometer flasks containing $200 \mu \mathrm{l}$ of Ringer plus $25 \mu \mathrm{l}$ of $3 \% \mathrm{BSA}$ and $50 \mu \mathrm{l}$ palmitate-1-14 $\mathrm{C}$ in water $(0.25$ to $0.37 \mathrm{~m} \mu$ moles, 23,000 to 35,000 counts $/ \mathrm{min})$. Incubation proceeded for $60 \mathrm{~min}$ at $25^{\circ} \mathrm{C}$ with shaking at 120 oscillations/min. The carbon dioxide, absorbed into $1 \mathrm{M}$ potassium hydroxide, was counted.

The relative oxidation and storage of fatty acid and of glucose were measured after 2-hr incubations in potassium palmitate-1-14 $\mathrm{C}$ or in D-glucose- ${ }^{14} \mathrm{C}(\mathrm{U})$. Pairs of fat bodies were incubated in a total volume of $0.5 \mathrm{ml}$ medium which contained $1 \mu \mathrm{c}$ of labelled substrate. The rinsed tissue was analysed after collection of the $\mathrm{CO}_{2}$. The fat bodies incubated with FFA were dried overnight at $65^{\circ} \mathrm{C}$ and were subsequently weighed, homogenized in $1.0 \mathrm{ml}$ chloroform-methanol $(1: 2, \mathrm{v} / \mathrm{v})$, and analysed for label in the glycerides following the method of FrITZ and KaPLAN (1961).

The fat bodies which were incubated with glucose were dried, weighed, and homogenized in $1.0 \mathrm{ml} 30 \%$ potassium hydroxide. Glycogen and other precipitable polysaccharides were precipitated from the homogenate by heating and addition of $95 \%$ ethanol according to the method of SEIFTER et al. (1950), and taken up in $1 \mathrm{ml}$ of water for counting.

\section{Haemolymph volume}

The dilution of a known amount of inulin-carboxyl- ${ }^{14} \mathrm{C}$ in the haemocoel was used to measure the haemolymph volume. A volume of $0 \cdot 2 \mu \mathrm{l}$ of inulin $(15 \cdot 2 \mu \mathrm{g} / \mu \mathrm{l}$; about 20,000 counts $/ \mathrm{min}$ ) was injected through the intersegmental membrane of the coxa of the right hindmost leg of $\mathrm{CO}_{2}$-anaesthetized adult females using a $1 \cdot 0 \mu \mathrm{l}$ Hamilton syringe fitted with a very fine glass needle. Since a minimum of $2 \mathrm{hr}$ is required for complete mixing in the haemocoel of Pyrrhocoris (MarTIN, 1968), the females were bled at $5 \mathrm{hr}$ after injection. Further confirmation of sufficient mixing was provided by taking two samples from each insect, one from the left front leg and one from the right hind leg. The average of the two samples was used to calculate haemolymph volume.

\section{Statistical analysis}

The Mann-Whitney U test (SIEGEL, 1956) was applied to comparable data on tissues of different ages, to ascertain the probability that groups of numerical data belong to the same numerical population. Two sets of numbers were considered significantly different if $P \leqslant 0.05$. Standard deviations were corrected for small sample size according to the table of Bliss and CalHoun (1954).

\section{RESULTS}

Distribution of labelled lipid in the fat body after in vivo incorporation of sodium palmitate-1-14 $\mathrm{C}$

The TG fraction contained most of the label in the fat body lipid after females had been fed labelled palmitate for 3 and 4 days. The fat bodies of 3 of the 4 
females examined contained an average of 94 per cent of the labelled lipid as TG and were within 8 per cent of each other, while in a fourth female TG accounted for 72 per cent of the labelled lipid. The average distribution of label ( 89 per cent TG, 6.5 per cent FFA, 4.5 per cent DG, and 0.5 per cent MG) closely resembles the lipid composition of the adult female fat body in which at least 95 per cent of the lipid is TG while DG and FFA account for the rest (MarTin, 1969).

Lipid release from the fat body in vitro

A. Effect of haemolymph. The presence of haemolymph from either adult Pyrrhocoris or pupal Hyalophora cecropia silkmoth, even at concentrations of 70 and $100 \%$, had no detectable effect on the rate of release of lipid from the fat body (Table 1). Consequently, the routine incubation medium for studies of lipid release contained only Ringer.

TABLE 1-EFFECT OF HAEMOLYMPH ON LIPID RELEASE FROM THE FAT BODY in vitro

\begin{tabular}{|c|c|c|c|c|}
\hline \multicolumn{2}{|c|}{ Rate of release } & \multirow[b]{2}{*}{$\begin{array}{c}\text { Factor of increase } \\
\text { (haemolymph/control) }\end{array}$} & \multirow[b]{2}{*}{$\begin{array}{c}\text { Concentration of } \\
\text { haemolymph } \\
(\%)\end{array}$} & \multirow[b]{2}{*}{ Source of haemolymph } \\
\hline $\begin{array}{c}\text { Control } \\
(\%)\end{array}$ & $\begin{array}{c}\text { With } \\
\text { haemolymph } \\
(\%)\end{array}$ & & & \\
\hline 10 & $\begin{array}{l}4 \\
4\end{array}$ & 0.4 & 10 & Pyrrhocoris \\
\hline $\begin{array}{l}2 \cdot 3 \\
4 \cdot 7\end{array}$ & $\begin{array}{l}3 \cdot 3 \\
3 \cdot 8\end{array}$ & $1 \cdot 0$ & 20 & Pyrrhocoris \\
\hline 1.4 & $2 \cdot 0$ & $1 \cdot 4$ & 20 & H. cecropia \\
\hline $6 \cdot 5$ & $\begin{array}{l}5 \cdot 1 \\
9 \cdot 9\end{array}$ & $1 \cdot 2$ & 20 & H. cecropia \\
\hline $5 \cdot 7$ & $\begin{array}{l}2 \cdot 1 \\
8 \cdot 5\end{array}$ & 0.9 & 20 & H. cecropia \\
\hline $\begin{array}{l}2 \cdot 6 \\
3 \cdot 0\end{array}$ & $\begin{array}{l}0 \cdot 8 \\
7 \cdot 1\end{array}$ & $1 \cdot 4$ & 20 & H. cecropia \\
\hline $\begin{array}{l}2 \cdot 3 \\
4 \cdot 7\end{array}$ & $1 \cdot 6$ & $0 \cdot 5$ & 70 & Pyrrhocoris \\
\hline $2 \cdot 3$ & $4 \cdot 8$ & $1 \cdot 4$ & 100 & Pyrrhocoris \\
\hline & & Average $1 \cdot 0$ & & \\
\hline
\end{tabular}

Release rate is expressed as percentage of label in fat body appearing in the surrounding medium $/ \mathrm{hr}$. Control incubation medium contained Ringer only. Incubations run in duplicate are listed separately.

B. Release in relation to age and physiological state. As shown in Table 2 , while there was considerable individual variation in the rate of lipid release, the average rate was the same on days 2,3 , and 4 , but was considerably increased on day 5 $(P=0.01,0.02$, and 0.002 for the comparison of day 5 with days 2,3 , and 4 , respectively). The rates of lipid release from fat bodies in ovariectomized females 
LIPIDS IN FAT BODY AND HAEMOLYMPH OF PYRRHOCORIS APTERUS

TABLE 2-RATE OF LIPID RELEASE in vitro FROM INDIVIDUAL FAT BODIES OF DIFFERENT AGES AND PHYSIOLOGICAL STATES

\begin{tabular}{|c|c|c|c|c|c|c|c|}
\hline Age & $\begin{array}{l}\text { Release } \\
\text { rate }\end{array}$ & Age & $\begin{array}{l}\text { Release } \\
\text { rate }\end{array}$ & Age & $\begin{array}{l}\text { Release } \\
\text { rate }\end{array}$ & Age & $\begin{array}{l}\text { Release } \\
\text { rate }\end{array}$ \\
\hline Day 2 & $\begin{array}{r}1.4 \\
2.0 \\
2.4 \\
2.4 \\
3.4 \\
5.8 \\
6.6 \\
7.2 \\
7.8 \\
8.4 \\
11.6\end{array}$ & Day 3 & $\begin{array}{r}1.6 \\
2.2 \\
2.5 \\
3.0 \\
4.8 \\
5.3 \\
5.7 \\
8.4 \\
8.4 \\
12.0 \\
12.6\end{array}$ & Day 4 & \multicolumn{2}{|l|}{$\begin{array}{l}2 \cdot 6 \\
2.7 \\
3.7 \\
5 \cdot 2 \\
6 \cdot 0 \\
7 \cdot 2 \\
7.8\end{array}$} & $\begin{array}{r}8 \cdot 7 \\
10 \cdot 6 \\
11 \cdot 4 \\
11 \cdot 8 \\
22 \cdot 9 \\
29 \cdot 8\end{array}$ \\
\hline Average & $5.4 \% / \mathrm{hr}$ & & $6.0 \% / \mathrm{hr}$ & & \multicolumn{2}{|l|}{$5.0 \% / \mathrm{hr}$} & $15.9 \% / \mathrm{hr}$ \\
\hline \multicolumn{2}{|c|}{$\begin{array}{l}\text { Ovariectomized } \\
\text { (Day 4) }\end{array}$} & $\begin{array}{r}5 \cdot 0 \\
11 \cdot 1\end{array}$ & $\begin{array}{l}\text { Diapause } \\
\text { (Day 16) }\end{array}$ & $\begin{array}{l}3.5 \\
\\
6.7 \\
9.3\end{array}$ & \multicolumn{3}{|c|}{$\begin{array}{l}\text { Fat body labelled by } \\
\text { in vitro incubation } \\
\text { Days } 2 \text { and } 3 \\
\end{array}$} \\
\hline Average & & $8 \cdot 1 \% / \mathrm{hr}$ & & $6 \cdot 5^{\circ}$ & $6 / \mathrm{hr}$ & & $6.3 \% / \mathrm{hr}$ \\
\hline
\end{tabular}

Rates are expressed as percentage of the labelled lipid in the fat body released/hr.

on day 4 and diapausing females were not distinguishable from the rates for reproducing females on days 2,3 , and 4 .

C. Composition of released lipid. The primary class of lipid released by the fat body in vitro, after in vivo labelling, was TG, which accounted for 90 per cent of the released lipid (Table 3, part $A$ ). The method used to label the fat body altered the composition of the lipid released. Both DG and FFA release were increased $2 \cdot 5$-fold $(P=0.018)$ and the proportion of TG released was significantly reduced $(P=0.036)$ when the tissue had been labelled by a brief, in vitro incubation of fat body in labelled palmitate (Table 3, part B) rather than by in vivo accumulation after ingestion of the label by the intact animal (part A). It is interesting that this did not alter the rate at which labelled lipid was released (Table 2).

D. Effect of dilution and agitation on the release rate. As seen in Table 4, the rate of release was more than tripled by adding Ringer to double the incubation volume after the first $60 \mathrm{~min}$. The rate of release was increased thirteenfold (from 8 counts/min to 110 counts/min) when the medium was bubbled with oxygen and an additional threefold (to 352 counts/min) when the oxygen was replaced with nitrogen. Agitation rather than aeration was presumably the factor responsible since the results were so similar for these two gases; the difference in rate with the two gases probably results from the difference in gas pressure. 
TABLE 3-Composition OF LIPIDS RELEASED BY THE FAT BODY in vitro

(A) Fat body labelled by feeding palmitate-1 ${ }^{14} \mathrm{C}$ for 3 to 4 days.

\begin{tabular}{cccccc}
\hline $\begin{array}{c}\text { Total counts/min in } \\
\text { sample of } \\
\text { released lipids }\end{array}$ & \multicolumn{6}{c}{$\begin{array}{l}\text { Percentage distribution of total counts } \\
\text { TG (\%) }\end{array}$} & DG (\%) & MG (\%) & FFA (\%) & $\begin{array}{c}\text { Incubation } \\
\text { medium }\end{array}$ \\
\hline 321 & 87 & 8 & 2 & 3 & $\begin{array}{c}\text { Ringer and } \\
\text { haemolymph }\end{array}$ \\
158 & 91 & 3 & 4 & 3 & Ringer \\
137 & 93 & 6 & 0 & 2 & Ringer \\
119 & 78 & 13 & 3 & 5 & Ringer \\
103 & 100 & 0 & 0 & 0 & Ringer \\
Average (\%) & 90 & 6 & 3 & 2 & \\
\hline
\end{tabular}

(B) Fat body labelled by in vitro incubation in palmitate-1 $-{ }^{14} \mathrm{C}$ for $60 \mathrm{~min}$.

\begin{tabular}{|c|c|c|c|c|c|}
\hline $\begin{array}{l}\text { Total counts } / \mathrm{min} \text { in } \\
\text { sample of } \\
\text { released lipids }\end{array}$ & \multicolumn{4}{|c|}{ Percentage distribution of total counts } & $\begin{array}{c}\text { Incubation } \\
\text { medium }\end{array}$ \\
\hline 488 & 76 & 18 & 2 & 5 & Ringer \\
\hline 461 & 76 & 17 & 1 & 5 & Ringer \\
\hline 413 & 81 & 13 & 2 & 5 & Ringer \\
\hline Average $(\%)$ & 78 & 16 & 2 & 5 & \\
\hline
\end{tabular}

Fat bodies were taken from females during the first reproductive cycle. The activity in fractions scored as 0 was indistinguishable from a silica gel blank.

TABLE 4-EFfect OF DILUTION ON THE RATE OF in vitro LIPID RELEASE BY THE FAT BODY

\begin{tabular}{ccc}
$\begin{array}{c}\text { Rate before } \\
\text { dilution }\end{array}$ & $\begin{array}{c}\text { Rate after } \\
\text { dilution }\end{array}$ & $\begin{array}{c}\text { Factor of } \\
\text { increase }\end{array}$ \\
\hline $3 \cdot 7$ & $18 \cdot 9$ & $5 \cdot 1$ \\
$7 \cdot 3$ & $17 \cdot 0$ & $2 \cdot 3$ \\
$7 \cdot 4$ & $36 \cdot 7$ & $5 \cdot 0$ \\
$8 \cdot 0$ & $19 \cdot 3$ & $2 \cdot 4$ \\
$8 \cdot 2$ & $23 \cdot 4$ & $2 \cdot 9$ \\
$10 \cdot 2$ & $81 \cdot 2$ & $8 \cdot 0$ \\
$11 \cdot 1$ & $38 \cdot 5$ & $3 \cdot 5$ \\
$13 \cdot 0$ & $51 \cdot 1$ & $3 \cdot 9$ \\
$14 \cdot 5$ & $75 \cdot 4$ & $5 \cdot 2$ \\
$16 \cdot 4$ & $49 \cdot 1$ & $3 \cdot 0$ \\
$17 \cdot 7$ & $28 \cdot 0$ & $1 \cdot 6$ \\
$19 \cdot 2$ & $46 \cdot 5$ & $2 \cdot 4$ \\
$41 \cdot 6$ & $90 \cdot 2$ & $2 \cdot 2$ \\
86.9 & $54 \cdot 1$ & $0 \cdot 6$ \\
& & Average \\
\hline
\end{tabular}

The volume of Ringer in the incubation medium was doubled at $60 \mathrm{~min}$. Rates are expressed as counts/min released per min. 
Uptake of lipid by the fat body in vitro

A. Effect of haemolymph, albumin, glucose, and trehalose. The presence of 5 per cent haemolymph resulted in an approximately three- to four-fold higher rate of lipid uptake (Table 5). The rate of uptake was no greater in $10 \%$ or $30 \%$ haemolymph than in $5 \%$. Haemolymph from male and female adults was equally

Table 5-Rate of Lipid UPTAKe by the eXcised Fat body in RiNGeR AND in RiNGER PLUS Pyrhocoris HAEMOLYMPH*

\begin{tabular}{|c|c|c|c|c|}
\hline Age of females & $\begin{array}{r}\text { Rate } \\
\text { in }\end{array}$ & $\begin{array}{l}\text { of uptake } \\
\text { Ringer }\end{array}$ & $\begin{array}{l}\text { Rate of uptake in } \\
5 \% \text { haemolymph }\end{array}$ & $\begin{array}{c}\text { Factor of increase } \\
\text { (haemolymph/Ringer) }\end{array}$ \\
\hline \multirow[t]{2}{*}{ Days 2 to 5} & & $\begin{array}{l}1 \cdot 3 \\
1.4\end{array}$ & $\begin{array}{l}2 \cdot 1 \\
4 \cdot 0 \\
4 \cdot 4 \\
5 \cdot 5\end{array}$ & \\
\hline & Average & $1.4 \%$ & $4.0 \%$ & $2 \cdot 9$ \\
\hline \multirow[t]{2}{*}{$\begin{array}{l}\text { Days } 7 \text { to } 8 \text {, } \\
\text { starved since } \\
\text { ecdysis }\end{array}$} & & $\begin{array}{l}2 \cdot 2 \\
3 \cdot 1\end{array}$ & $\begin{array}{r}6 \cdot 4 \\
6 \cdot 7 \\
7 \cdot 5 \\
10 \cdot 4\end{array}$ & \\
\hline & Average & $2 \cdot 7 \%$ & $7 \cdot 8 \%$ & $2 \cdot 9$ \\
\hline \multirow[t]{2}{*}{$\begin{array}{l}\text { Days } 14 \text { to } 18 \\
\text { starved since } \\
\text { ecdysis }\end{array}$} & & $\begin{array}{l}2.2 \\
3.6\end{array}$ & $\begin{array}{l}13 \cdot 4 \\
12 \cdot 2\end{array}$ & \\
\hline & Average & $2.9 \%$ & $12 \cdot 8 \%$ & $4 \cdot 4$ \\
\hline
\end{tabular}

Rates given are for individual fat bodies and are expressed as percentage of surrounding lipid taken up/mg fat body in $30 \mathrm{~min}$ in vitro.

* $100 \mu \mathrm{l}$ incubation medium contained 0.0031 to $0.0050 \mu$ moles palmitate $-1-{ }^{14} \mathrm{C}$.

effective. Bovine serum albumin at $3 \%$ was as effective as haemolymph (Table 6 ). Glucose and trehalose did not have a significant effect on the rates of fatty acid uptake or of esterification at a concentration of $3 \%$ (Table 7).

B. Time course of fatty acid uptake and esterification. As shown in Fig. 1, the incorporation of fatty acid into the fat body in vitro was essentially linear during the first $30 \mathrm{~min}$ of incubation for all ages. The esterification of this fatty acid into neutral lipids was extremely rapid, averaging 79 per cent (range 71-89 per cent) of the palmitate taken up after only 5 min of incubation (Fig. 2). The rate of esterification during $30 \mathrm{~min}$ of incubation was essentially constant for each age.

C. Rate of fatty acid uptake in relation to age and physiological state. As shown in Fig. 3 and Table 8, lipid uptake by the fat body increased to its maximum level by the second day after ecdysis, remained high through the third day when vitellogenesis began, and then decreased to its minimum on the fourth and fifth 


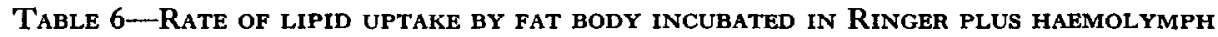
OR BOVINE SERUM ALBUMIN

\begin{tabular}{|c|c|c|c|c|c|c|}
\hline & & & $\begin{array}{c}\text { Rate of } \\
\text { uptake in } \\
3 \% \text { BSA } \\
(\%)\end{array}$ & $\begin{array}{c}\text { Proportion } \\
\text { esterified } \\
(\%)\end{array}$ & $\begin{array}{c}\text { Rate of } \\
\text { uptake in } 5 \% \\
\text { haemolymph } \\
(\%)\end{array}$ & $\begin{array}{c}\text { Proportion } \\
\text { esterified } \\
(\%)\end{array}$ \\
\hline \multirow{2}{*}{\multicolumn{2}{|c|}{$\begin{array}{l}\text { (a) Fat bodies from } \\
\text { normal females }\end{array}$}} & & $\begin{array}{r}7 \cdot 1 \\
10 \cdot 7\end{array}$ & $\begin{array}{l}86 \\
89\end{array}$ & $\begin{array}{l}6 \cdot 2 \\
6 \cdot 3\end{array}$ & $\begin{array}{l}84 \\
89\end{array}$ \\
\hline & & Average & 8.9 & $87 \cdot 5$ & $6 \cdot 3$ & $86 \cdot 5$ \\
\hline \multirow{2}{*}{\multicolumn{2}{|c|}{$\begin{array}{l}\text { (b) Fat bodies from } \\
\text { starved females }\end{array}$}} & & $\begin{array}{l}3 \cdot 3 \\
5 \cdot 9\end{array}$ & $\begin{array}{l}91 \\
86\end{array}$ & $\begin{array}{l}4 \cdot 0 \\
5 \cdot 3 \\
6 \cdot 5\end{array}$ & $\begin{array}{l}82 \\
84 \\
73\end{array}$ \\
\hline & & Average & e 4.6 & $88 \cdot 5$ & $5 \cdot 3$ & 80 \\
\hline
\end{tabular}

The incubation conditions and the form in which results are expressed are the same as in Table 5.

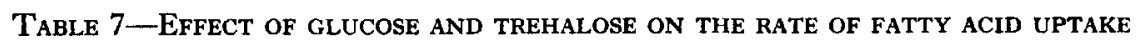
AND ESTERIFICATION BY THE EXCISED FAT BODY

(A) Glucose

\begin{tabular}{cccccc}
\hline & \multicolumn{2}{c}{ Rate of lipid uptake } & \multicolumn{2}{c}{ Proportion esterified } \\
\cline { 2 - 3 } \cline { 5 - 6 } & $\begin{array}{c}3 \%(\mathrm{w} / \mathrm{w}) \text { Glucose } \\
\text { (counts/min) }\end{array}$ & $\begin{array}{c}\text { Control } \\
\text { (counts/min) }\end{array}$ & & $\begin{array}{c}3 \% \text { Glucose } \\
(\%)\end{array}$ & $\begin{array}{c}\text { Control } \\
(\%)\end{array}$ \\
\hline (1) & 167 & 480 & 81 & 87 \\
& 464 & 657 & 80 & 84 \\
(2) & 2390 & 2520 & & \\
\hline
\end{tabular}

(B) Trehalose

\begin{tabular}{cccccc}
\hline \multicolumn{2}{c}{ Rate of lipid uptake } & & \multicolumn{2}{c}{ Proportion esterified } \\
\cline { 2 - 3 } \cline { 5 - 6 } $\begin{array}{c}3 \%(\mathrm{w} / \mathrm{w}) \text { Trehalose } \\
(\text { counts } / \mathrm{min})\end{array}$ & $\begin{array}{c}\text { Control } \\
\text { (counts } / \mathrm{min})\end{array}$ & & $\begin{array}{c}3 \% \\
\text { Trehalose } \\
(\%)\end{array}$ & $\begin{array}{c}\text { Control } \\
(\%)\end{array}$ \\
\hline 730 & 970 & 80 & 78 \\
770 & 1250 & & 80 & 72 \\
1410 & 1530 & & 81 & 86 \\
& & 1250 & 80 & 79 \\
\hline
\end{tabular}

The fat bodies were incubated as described in Table 5 with $5 \%$ haemolymph. Uptake rate is expressed as counts $/ \mathrm{min}$ taken up per $\mathrm{mg}$ tissue in $30 \mathrm{~min}$. Proportion esterified is the percentage of the label taken up in 30 min which was extracted as neutral lipids. 


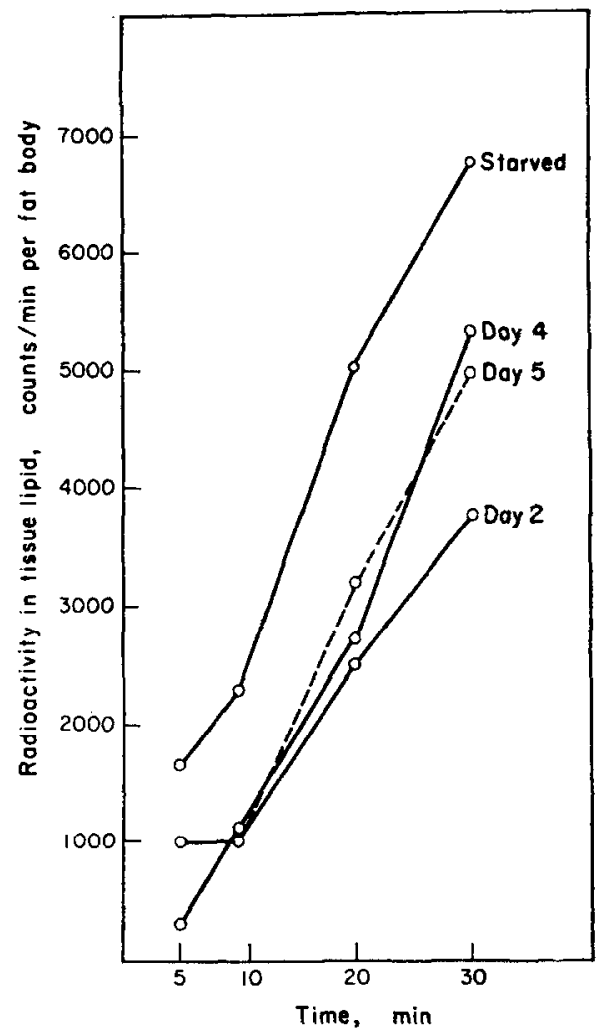

FIG. 1. Amount of labelled fatty acid taken up/fat body during $30 \mathrm{~min}$ of in vitro incubation. Each point is the measurement of one fat body. Each fat body of a given age was incubated in the same amount of palmitate $-1{ }^{14} \mathrm{C}$. Starved females had not fed for 12 days.

days, when oöcytes were maturing. The most dramatic and interesting change was the decrease in rate after day 3 . On the basis of dry weight, the rates on day 2 and day 3 were not significantly different from one another, but both were higher than those on day $4(P=0.008)$ and day $5(P=0.001$ and 0.003$)$. It is interesting and important to observe that the overall pattern of change in rate of uptake is not simply a matter of the change in tissue mass which occurs at this time, but is apparent both on a 'per $\mathrm{mg}$ ' and 'per fat body' basis.

After ovariectomy, the rate of uptake by the day 4 fat body was twice as high as the normal, oöcyte-producing day 4 female $(P=0 \cdot 014)$, similar to the normal rate of the second and third days (Table 8). During diapause, the rate of uptake was low, being statistically indistinguishable from the rate on day $5(P=0.416)$ and significantly different from the rates on every other day in active females $(P<0 \cdot 02)$.

After 18 days of starvation, the rate of uptake increased to three times the normal rate when measured on the basis of dry weight (Table 8 ). This increase 
in rate on a 'per mg' basis can be accounted for by the decrease in weight of the fat body that occurs during starvation of Pyrrhocoris (MARTIN, 1969). When the rates of uptake are expressed 'per fat body' the values observed for starved females lie in the range of the rates for fat bodies of normally feeding females on days 1 to 3 .

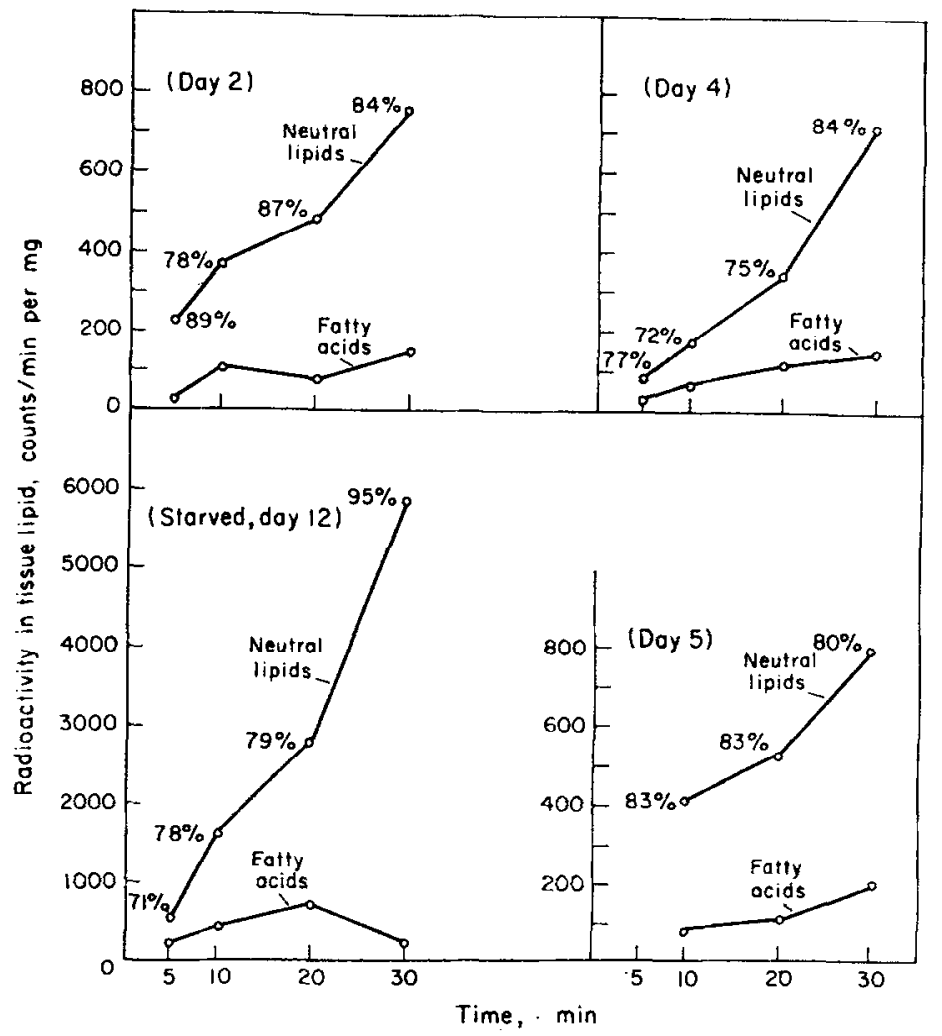

FIG. 2. Time course of uptake and esterification of fatty acid by fat body in vitro. The data are from the same experiments shown in Fig. 1. Percentage values are the proportion of the total lipid taken up which was esterified.

D. Uptake of diglyceride and triglyceride. As shown in Table 9, considerably less TG than FFA was taken up, while DG was incorporated to a greater extent than FFA when incubated in the same amount of haemolymph (5 $\mu \mathrm{l})$ (and, thus, in the same amount of lipid). The presence of $50 \mu \mathrm{l}$ of haemolymph in the $100 \mu \mathrm{l}$ of incubation medium did not affect the amount of 'TG taken up but decreased the amount of DG incorporated to one-third the amount in $5 \mu \mathrm{l}$ of haemolymph (Table 9).

\section{Haemolymph lipids}

TG accounted for more than 50 per cent of the haemolymph lipid during the entire reproductive cycle (Table 10). DG was the secondary constituent and 
increased in amount during this period, accounting for the increase in lipid concentration in the haemolymph which occurred at this time. FFA was a relatively minor component, and MG, sterol, and steryl esters were not detected in $50 \mu \mathrm{l}$ of haemolymph, indicating that if present at all, their concentrations are less than $0 \cdot 3 \mu \mathrm{g} / \mu \mathrm{l}$.

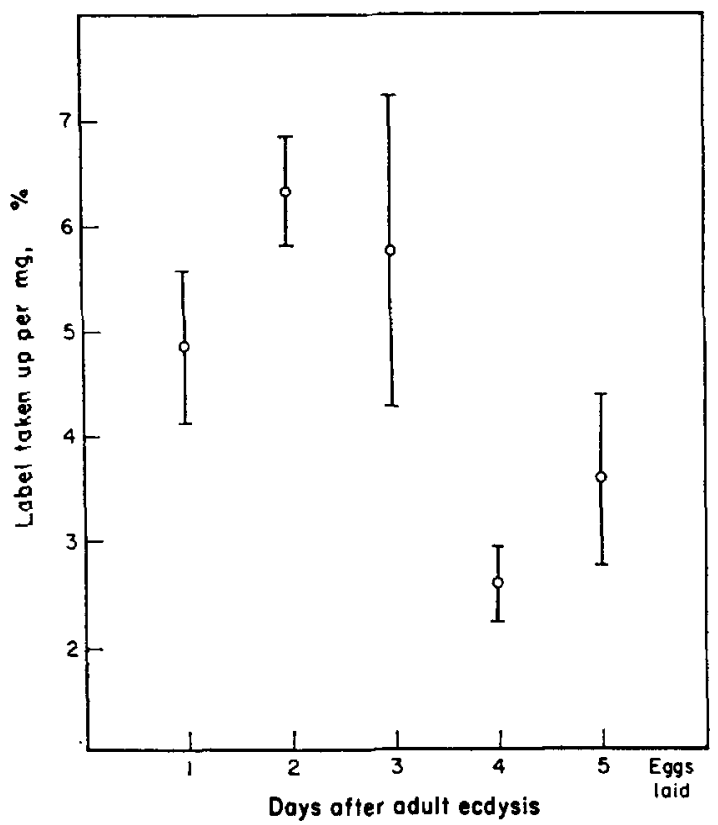

FIG. 3. Rate of in vitro lipid incorporation/mg dry wt. by fat bodies of different ages. Results are expressed as percentage of the palmitate-1 ${ }^{14} \mathrm{C}$ incorporated by the fat body in $30 \mathrm{~min} / \mathrm{mg}$ of tissue. These are the means and standard deviations of 4 to 8 fat bodies of each age.

In diapausing females (Table 11), the concentration of lipid in the haemolymph was high, equal to that in active, day 5 females, while the proportion of DG remained low.

Starvation reduced the haemolymph lipid concentration markedly and rapidly (Table 11). After only 2 days without food, the lipid concentration was only onequarter the normal value and it remained depressed during 20 days of starvation. The proportion of TG remained high, averaging approximately the same value found on the day after ecdysis.

\section{Haemolymph volume}

The volume of haemolymph in normal adult females was $23 \mu \mathrm{l}$ (Table 12). During the reproductive cycle no statistically significant change was detected. However, the mean for each age was used in calculations involving haemolymph volume. 
Table 8-Proportion of external palmitate-1-14 C taken up in $30 \mathrm{~min}$ BY eXcised FAT BODIES FROM FEMALES WHICH WERE (1) REPRODUCING, (2) OVARIECTOMIZED,

(3) IN DIAPAUSE, AND (4) STARVED

\begin{tabular}{|c|c|c|c|c|}
\hline \multirow{2}{*}{\multicolumn{2}{|c|}{ Type of female }} & \multirow[b]{2}{*}{ Age } & \multicolumn{2}{|c|}{$\begin{array}{l}\text { Percentage of label } \\
\text { taken up }\end{array}$} \\
\hline & & & per fat body & per mg \\
\hline (1) & $\begin{array}{l}\text { Reproducing } \\
\text { (means of } 4 \text { to } 8 \text { females) }\end{array}$ & $\begin{array}{l}\text { Day } 1 \\
\text { Day } 2 \\
\text { Day } 3 \\
\text { Day } 4 \\
\text { Day } 5\end{array}$ & $\begin{array}{l}13 \cdot 7 \\
22 \cdot 1 \\
21 \cdot 1 \\
13 \cdot 2 \\
11 \cdot 6\end{array}$ & $\begin{array}{l}4 \cdot 9 \\
6 \cdot 4 \\
5 \cdot 8 \\
2 \cdot 6 \\
3 \cdot 6\end{array}$ \\
\hline (2) & $\begin{array}{l}\text { Ovariectomized } \\
\text { (Day 4) }\end{array}$ & Average & $\begin{array}{l}23.4 \\
21 \cdot 1 \\
17.6 \\
21.6 \\
20.9 \%\end{array}$ & $\begin{array}{l}3 \cdot 9 \\
4 \cdot 4 \\
4 \cdot 8 \\
7 \cdot 1 \\
5 \cdot 1 \%\end{array}$ \\
\hline (3) & Diapausing & Average & $\begin{array}{l}14 \cdot 7 \\
18 \cdot 7 \\
15 \cdot 3 \\
19 \cdot 7 \\
19 \cdot 1 \\
17 \cdot 5 \%\end{array}$ & $\begin{array}{l}2 \cdot 2 \\
2 \cdot 9 \\
3 \cdot 9 \\
4 \cdot 0 \\
4 \cdot 0 \\
3 \cdot 4 \%\end{array}$ \\
\hline (4) & Starved & $\begin{array}{r}2 \text { days } \\
2 \text { days } \\
8 \text { days } \\
8 \text { days } \\
18 \text { days } \\
18 \text { days }\end{array}$ & $\begin{array}{l}17 \cdot 8 \\
22 \cdot 9 \\
19 \cdot 2 \\
25 \cdot 0 \\
17 \cdot 0 \\
16 \cdot 0\end{array}$ & $\begin{array}{r}4 \cdot 9 \\
7 \cdot 3 \\
12 \cdot 8 \\
19 \cdot 1 \\
17 \cdot 2 \\
18 \cdot 6\end{array}$ \\
\hline
\end{tabular}

Microscopic examination of haemolymph lipid

The adult female Pyrrhocoris bleeds readily when an appendage is cut; the haemolymph samples pictured in Figs. 4 to 6 and 8 to 9 were taken from the distal end of an appendage without applying pressure, thus the lipid was not squeezed from some other tissue by experimental manipulation. The haemolymph contains large aggregates of lipid (Fig. 4) and numerous lipid droplets (Fig. 5) as well as aggregates of lipid in what appear to be cells (Fig. 6). In fresh preparations the cells of the fat body (Fig. 7) resemble the cell-like aggregates of lipid ('adipocytes') in the haemolymph (Fig. 6). The adipocytes are much larger than the usual blood cells (Fig. 8, see arrow). After a few days of starvation the number of adipocytes in the haemolymph is considerably reduced while many lipid droplets remain visible (Fig. 5). The lipid-filled cell-like objects in the haemolymph are considered to be cells on the basis of their apparent Feulgen-positive nuclei (Fig. 9). 

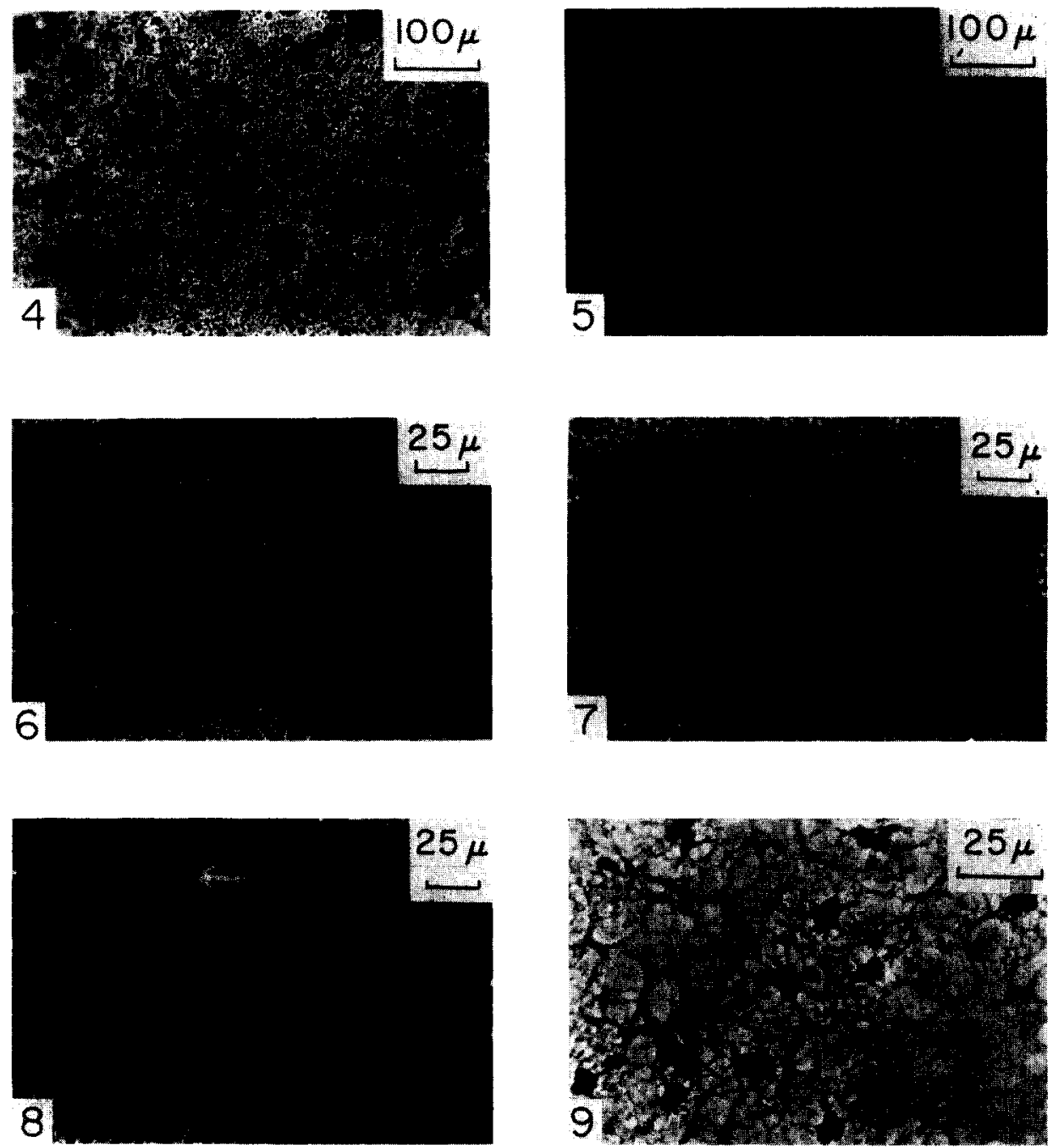

Fig. 4. Fresh haemolymph, day 3 female, under phase contrast.

FIg. 5. Fresh haemolymph, starved day 4 female, under phase contrast.

Fig. 6. Fresh haemolymph, day 0 female, under phase contrast.

Fig. 7. Fresh fat body, day 3 female, under phase contrast.

Fig. 8. Fresh haemolymph, fifth instar, under phase contrast.

FIG. 9. Feulgen-stained haemolymph, day 4 female. 
TABLE 9-Lipid UPTAKe BY THE Fat BODY OF 2- aNd 3-day-old FEMALES WHEN INCUBATED IN A TOTAL OF $100 \mu \mathrm{l}$ OF HAEMOLYMPH, RINGER, AND EITHER PALMITATE$1-{ }^{14} \mathrm{C}$, OR TRIPALMITIN- $1-{ }^{14} \mathrm{C}$, OR DIGLYCERIDE- ${ }^{14} \mathrm{C}$

\begin{tabular}{|c|c|c|c|c|}
\hline & $\begin{array}{l}\text { Perc } \\
\text { label } t\end{array}$ & $\begin{array}{l}\text { entage of } \\
\text { aken up } / \mathrm{mg}\end{array}$ & $\begin{array}{c}\text { Percentage of } \\
\text { incorporated label } \\
\text { present as neutral } \\
\text { lipid }\end{array}$ & $\begin{array}{c}\text { Amount of } \\
\text { haemolymph } \\
(\mu 1)\end{array}$ \\
\hline${ }^{T G}-{ }^{14} \mathrm{C}$ & Average & $\begin{array}{l}1.6 \\
0.8 \\
0.6 \\
2.1 \\
2.4 \\
2.4 \\
1.7\end{array}$ & $\begin{array}{l}81 \\
78 \\
60 \\
26 \\
61 \\
87 \\
66\end{array}$ & $\begin{array}{r}5 \\
50 \\
50 \\
50 \\
50 \\
50\end{array}$ \\
\hline $\begin{array}{r}\text { FFA- }{ }^{14} \mathrm{C} \\
\text { Day } 2 \\
\text { Day } 3\end{array}$ & eans of $f i$ & $\begin{array}{l}\text { ve measurem } \\
6 \cdot 4 \\
5 \cdot 8\end{array}$ & nts each) & $\begin{array}{l}5 \\
5\end{array}$ \\
\hline$D G-{ }^{14} \mathrm{C}$ & Average & $\begin{array}{l}2 \cdot 5 \\
3 \cdot 8 \\
3 \cdot 2\end{array}$ & $\begin{array}{l}84 \\
80 \\
82\end{array}$ & $\begin{array}{l}50 \\
50\end{array}$ \\
\hline $\mathrm{DG}-{ }^{14} \mathrm{C}$ & Average & $\begin{array}{l}9 \cdot 3 \\
9 \cdot 7 \\
9 \cdot 5\end{array}$ & $\begin{array}{l}92 \\
91 \\
92\end{array}$ & $\begin{array}{l}5 \\
5\end{array}$ \\
\hline
\end{tabular}

Results represent individual fat bodies, except where noted, and are expressed as percentage of label taken up $/ \mathrm{mg}$ in $30 \mathrm{~min}$.

The haemolymph droplets and cellular inclusions stained positively for lipid in Sudan Black.

\section{Lipid utilization by the fat body}

The possibility was examined that lipid oxidation by the fat body increased during the period of rapid ovarian growth (days 3 to 5 ) and was responsible for the net loss of lipid in the fat body on days 4 and 5 (cf. MarTin, 1969). As shown in Table 13, a change in rate of lipid oxidation was observed; however, the increase in lipid metabolism on days 3 and 4 or 4 and 5 as compared with day 2 which would account for the observed decrease in amount of fat body lipid did not occur. On the basis of whole fat body, the rates on days 2,3 , and 4 were not significantly different, and on the basis of dry weight, the rates on days 3,4 , and 5 were not more than on day 2 .

Measurements of the disposition by excised fat body of external glucose and palmitate show that in $P$. apterus, lipid is preferentially stored by the fat body and glucose is preferentially degraded. Thus, when 14 pairs of fat bodies from day 0 to day 4 were incubated with palmitate-1-14 $\mathrm{C}$, in the presence of bovine serum 
TABLE 10-LiPID COMPOSITION IN HAEMOLYMPH of $P$. apterus DURING FIRST 5 days AFTER THE LARVAL-ADULT ECDYSIS

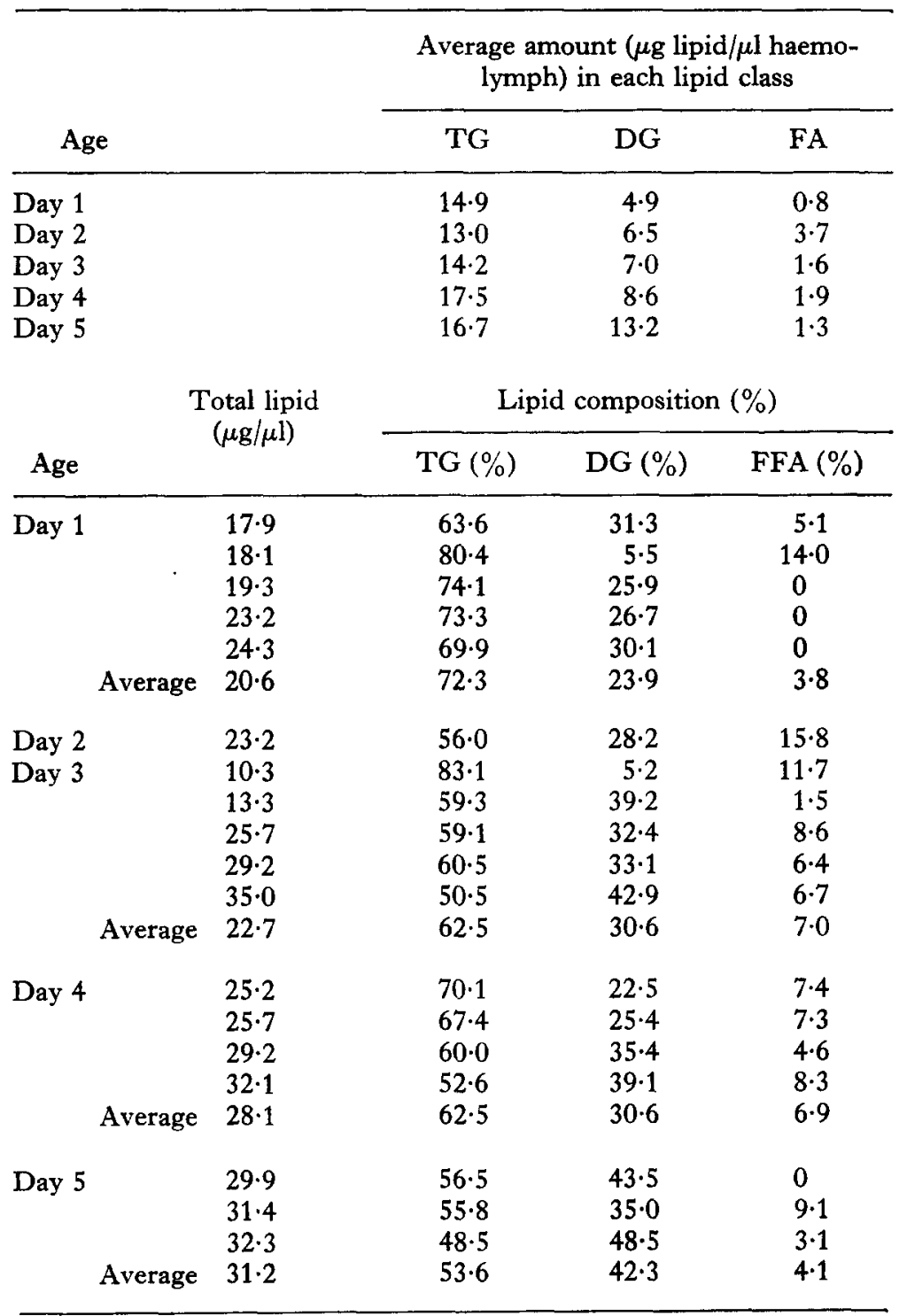

Haemolymph from 2 to 5 females was pooled for cach mcasurement.

albumin in Ringer, an average of 19.6 times as much label was incorporated into neutral lipids as catabolized to carbon dioxide. On the other hand, when 24 pairs of comparable fat bodies were incubated with glucose- ${ }^{14} \mathrm{C}(\mathrm{U})$ in Ringer, an average of 8.3 times as much label appeared in carbon dioxide as in glycogen. 
LIPIDS IN FAT BODY AND HAEMOLYMPH OF PYRRHOCORIS APTERUS

TABLE 11-LipID COMPOSITION IN HAEMOLYMPH OF $P$. apterus WHEN STARVED OR IN DIAPAUSE

\begin{tabular}{|c|c|c|c|c|}
\hline \multirow[b]{2}{*}{ Condition } & \multirow{2}{*}{$\begin{array}{l}\text { Total lipid } \\
(\mu \mathrm{g} / \mu \mathrm{l})\end{array}$} & \multicolumn{3}{|c|}{ Lipid composition } \\
\hline & & TG (\%) & DG $(\%)$ & FFA $(\%)$ \\
\hline Diapause & $31 \cdot 1$ & $78 \cdot 1$ & $21 \cdot 9$ & 0 \\
\hline \multicolumn{5}{|l|}{ Starved } \\
\hline Day 2 & $6 \cdot 4$ & $72 \cdot 9$ & $8 \cdot 3$ & $18 \cdot 8$ \\
\hline Day 10 & $6 \cdot 0$ & $61 \cdot 1$ & $11 \cdot 1$ & $27 \cdot 8$ \\
\hline Day 11 & $11 \cdot 1$ & $68 \cdot 1$ & $31 \cdot 9$ & 0 \\
\hline \multirow[t]{3}{*}{ Day 20} & $8 \cdot 3$ & $80 \cdot 0$ & $20 \cdot 0$ & 0 \\
\hline & $8 \cdot 6$ & $75 \cdot 6$ & $24 \cdot 4$ & 0 \\
\hline & $10 \cdot 5$ & $62 \cdot 0$ & $38 \cdot 0$ & 0 \\
\hline Starved, average & e 8.5 & $70 \cdot 0$ & $22 \cdot 3$ & $7 \cdot 8$ \\
\hline
\end{tabular}

Haemolymph from 2 to 5 females was pooled for each measurement.

Table 12-Volume of HaEmolymph IN ADULT FEMales MEASURED BY DILUTION OF CARBOXYL- ${ }^{14} \mathrm{C}$-INULIN

\begin{tabular}{|c|c|c|c|}
\hline Age & $\begin{array}{l}\text { Volume } \\
(\mu \mathrm{l})\end{array}$ & Aye & $\begin{array}{l}\text { Volume } \\
(\mu \mathrm{l})\end{array}$ \\
\hline Day 2 & $\begin{array}{l}17 \\
20 \\
21 \\
23\end{array}$ & Day 3 & $\begin{array}{l}21 \\
24 \\
30\end{array}$ \\
\hline Average & 20 & Average & 25 \\
\hline Day 4 & $\begin{array}{l}21 \\
21 \\
32\end{array}$ & Day 5 & $\begin{array}{l}18 \\
21 \\
23 \\
27\end{array}$ \\
\hline Average & 25 & Average & 22 \\
\hline
\end{tabular}

\section{DISCUSSION}

\section{Lipid incorporation}

A. Effect of haemolymph on uptake of lipid by the fat body. The three- to four-fold increase in rate of uptake which occurred in 5\% haemolymph (Table 5) suggests that some component of the haemolymph alters the fat body or associates with the lipid available for uptake in a way that facilitates its entry into the fat body. Since BSA was equally effective, the factor responsible for the increase is apparently not an insect hormone or a factor unique to insects. The facilitating effect may result 
TABLe 13-Amount of Palmitate- $1-{ }^{14} \mathrm{C}$ CONVERTEd to $\mathrm{CO}_{2}$ IN $60 \mathrm{~min}$ BY INDividual FAT BODIES OF ACTIVE FEMALES DURING THE FIRST 5 days OF ADULT LIFE INCUBATED IN SODIUM PALMITATE- $1-{ }^{14} \mathrm{C}$

\begin{tabular}{|c|c|c|c|c|c|c|}
\hline Age & & $\% / \mathrm{mg}$ & $\% /$ fat body & Age & $\% / \mathrm{mg}$ & $\% /$ fat body \\
\hline \multirow[t]{7}{*}{ Day 2} & & - & - & \multirow[t]{7}{*}{ Day 3} & 0.5 & $3 \cdot 0$ \\
\hline & & $1 \cdot 3$ & $3 \cdot 1$ & & $0 \cdot 6$ & $3 \cdot 0$ \\
\hline & & $1 \cdot 2$ & $2 \cdot 8$ & & 0.9 & $4 \cdot 3$ \\
\hline & & $1 \cdot 2$ & $2 \cdot 8$ & & 0.8 & 3.0 \\
\hline & & 1.0 & $3 \cdot 1$ & & 0.8 & $2 \cdot 8$ \\
\hline & & $1 \cdot 2$ & $2 \cdot 0$ & & & $3 \cdot 3$ \\
\hline & Average & $1 \cdot 2$ & $2 \cdot 8$ & & 0.7 & $3 \cdot 2$ \\
\hline \multirow[t]{15}{*}{ Day 4} & & $1 \cdot 3$ & $2 \cdot 6$ & \multirow[t]{7}{*}{ Day 5} & $1 \cdot 3$ & $1 \cdot 4$ \\
\hline & & 0.8 & $1 \cdot 7$ & & 0.8 & $2 \cdot 4$ \\
\hline & & $1 \cdot 0$ & $3 \cdot 2$ & & $1 \cdot 4$ & $1 \cdot 8$ \\
\hline & & 0.8 & $3 \cdot 1$ & & $1 \cdot 8$ & $2 \cdot 0$ \\
\hline & & $0 \cdot 8$ & $2 \cdot 7$ & & $1 \cdot 3$ & $1 \cdot 7$ \\
\hline & & $1 \cdot 0$ & $3 \cdot 9$ & & & \\
\hline & Average & $1 \cdot 0$ & $2 \cdot 9$ & & $1 \cdot 3$ & $1 \cdot 9$ \\
\hline & \multicolumn{5}{|c|}{ Mann-Whitney $U$ test } & \\
\hline & \multicolumn{3}{|c|}{ Results as $\% / \mathrm{mg}$ (dry wt.) } & \multicolumn{2}{|c|}{ Results as $\% /$ fat body } & \\
\hline & Ages & s compared & $P$ & Ages compared & $P$ & \\
\hline & & 2 and 3 & $0 \cdot 004$ & 2 and 3 & $0 \cdot 123$ & \\
\hline & & 3 and 4 & 0.063 & 3 and 4 & $0 \cdot 242$ & \\
\hline & & 4 and 5 & $0 \cdot 123$ & 4 and 5 & $0 \cdot 015$ & \\
\hline & & 2 and 5 & $0 \cdot 075$ & 2 and 5 & $0 \cdot 008$ & \\
\hline & & 3 and 5 & $0 \cdot 028$ & 3 and 5 & 0.002 & \\
\hline
\end{tabular}

Results are expressed as percentage of supplied label occurring as $\mathrm{CO}_{2}$.

simply from formation of a fatty acid-protein complex as is known to occur in a mixture of mammalian serum and fatty acid (Fredrickson and Gordon, 1958). Lipoprotein complexes have been found in insect haemolymph in a variety of species (Siakotos, 1960; Tietz, 1962; Chino and GilberT, 1965) including Pyrrhocoris (Sláma, personal communication). TiETz (1962) found that the fat body was required for lipoprotein formation in locust haemolymph. If a fatty acid-protein complex is formed in Pyrrhocoris haemolymph in vitro, it may be made possible by the presence of lipid-filled cells which, if they are derived from the fat body, may retain some physiological capabilities characteristic of fat body.

B. Rate of uptake of lipid by Pyrrhocoris fat body. In order to compare the present data with previous studies of lipid uptake, two assumptions have been made. Where the amount of lipid taken up was not measured at 30 min [cockroaches (GILBERT, 1967a; CoOK and EDdington, 1967) and Cecropia silkmoth (Chino and Gilbert, 1965)], the value for $60 \mathrm{~min}$ of incubation was halved. Fresh tissue weights have been reduced by a factor of 3.2 which is the approximate ratio 
of fresh to dry fat body weight in Pyrrohcoris. The 'lean dry weight' of Leucophaea (GILBERT, 1967a) was converted to dry weight by adding the lipid weight.

The rate of FFA incorporation in vitro by the fat body of adult female Pyrrhocoris during the first reproductive cycle $(2.6$ per cent to 6.4 per cent $/ \mathrm{mg}$ dry wt. in $30 \mathrm{~min}$ ) is about ten times greater than that of the cockroach Periplaneta americana (0.3 per cent; CoOK and EDDINGTON, 1967), the cockroach Leucophaea maderae (0.4 per cent; data from Fig. 7 in GILBERT, 1967a), the locust Locusta migratoria (0.5 per cent; TrFTz, 1962), the larval waxmoth, Galleria mellonella (0.6 per cent; WLODAWER and LĄGWIŃSKA, 1967), and the adult Hyalophora cecropia $(0.85$ per cent; Chino and GILBERT, 1965). The rate of TG uptake is also much higher in Pyrrhocoris fat body (1.7 per cent) than in fat bodies of L. migratoria $(0.076$ per cent; TIETZ, 1962) and waxmoth larvae $(0.02$ and 0.27 per cent, WLODAWER and LąGWIŃSKa, 1967). It is not possible to compare the rate of uptake of DG in Pyrrhocoris with that in other insects since no data on other insects are available.

Several factors suggest that DG may be the primary form of lipid taken up by Pyrrhocoris fat body in vivo. First, a somewhat larger proportion of DG was taken up in vitro by the day 2 to 3 fat body than was FFA, and TG was taken up far less (Table 9). Moreover, the rate of uptake is reduced in fat bodies on days 4 and 5 and the concentration of DG in the haemolymph rises steadily from $6.0 \mu \mathrm{g} / \mu \mathrm{l}$ (average for days 1,2 , and 3) to more than twice that concentration by day 5 (Table 10). Thus, when uptake decreases, DG accumulates in the haemolymph (presumably coming from the digestive tract). Furthermore, it would be advantageous for the fat body to take up a different form of lipid from that released in order to avoid recirculating the same lipid. Of course, it is possible that the lipids are distinguished physiologically by some characteristic not perceived by the techniques of separation employed here, such as by association with specific proteins. However, TG is the primary form of lipid released by the fat body; if DG is the primary form taken up, then the fat body would not be taking up the lipid it had released.

C. Rate of esterification of FFA by Pyrrhocoris fat body. The palmitate not oxidized was esterified into glycerides in Pyrrhocoris fat body nearly as fast as it was taken up (79 per cent in 5 min; Fig. 2). In contrast, the waxmoth fat body had esterified only 30 per cent of the FFA taken up after 5 min (WLODAWER and LĄGWIŃSKa, 1967); the locust fat body esterified 39 per cent at 10 min (TIETZ, 1962), and the Leucophaea fat body esterified 53 per cent at 15 min (GILBERT, $1967 \mathrm{a})$.

The high rate of esterification in Pyrrhocoris fat body may be explained by its ability to esterify FFA without an external source of glyceride-glycerol precursor. Mammalian adipose tissue requires carbohydrate to serve as glycerol precursor (BALLY et al., 1960). Glucose increases the rates of both FFA uptake and esterification by adipose tissue in vitro (LEBCEU, 1965). The fact that glucose and trehalose had no effect on the rates of uptake and esterification of FFA in Pyrrhocoris fat body (Table 7) implies that the fat body is able to utilize the glyceride moiety of 
DG taken up, or tissue carbohydrate as a source of the glyceride-glycerol moiety. The possibility that the haemolymph in the incubation medium provided the source of glyceride-glycerol is ruled out because incubation in BSA and Ringer yielded similar rates of uptake and esterification.

WLODAWER and LĄGWIŃSKA (1967) report that when glucose is not added to the incubation medium, the rate of FFA esterification by waxmoth larval fat body is reduced by 35 per cent. This requirement for exogenous carbohydrate emphasizes that fat bodies of different insect groups have different physiological capabilities. It is consistent with the above conclusion that the waxmoth fat body, which utilizes exogenous carbohydrate, has a very low rate of esterification while Pyrrhocoris fat body, which does not require carbohydrate to be transported into the tissue for glyceride synthesis, shows a negligible time lag in the incorporation of fatty acid into glyceride.

\section{Lipid release}

A. The rate of release and the effect of haemolymph. The rate at which Pyrrhocoris fat body released lipid in vitro ( 5 to 16 per cent/hr) is unusually low compared to other insects [48 per cent/hr for L. migratoria (TIETz, 1962), 19 to $27 \mathrm{per}$ cent $/ \mathrm{hr}$ for adult $H$. cecropia (ChINo and GilBeRT, 1965), and 41 per cent/hr for $P$. americana (COOK and EDDINGTON, 1967)]. The presence of haemolymph considerably increased the rate of lipid release in the migratory locust (TIETz, 1962), the Cecropia silkmoth, Melanoplus differentialis, and P. americana (CHINO and GILBERT, 1965). Since both H. cecropia and Pyrrhocoris haemolymph, even at concentrations of 70 to $100 \%$, had no effect on lipid release by Pyrrhocoris fat body in vitro, and the rate of release is considerably lower than in other species, a different physiological mechanism of lipid release in Pyrrhocoris may be implicated.

B. The form of lipid released. Although GILBERT (1967b) has suggested that DG may be the form in which lipid is released from the fat body in many or all insects, generalization on this point is premature. While the major form of lipid released in vitro is DG in $H$. cecropia (CHINo and GiLBerT, 1965) and in $L$. migratoria (TIETz, 1967), it is FFA in four species of cockroach (BHAKTHAN and GILBERT, 1968) and in the waxmoth larva (WLODAWER and BARAŃSKA, 1965) and it is TG in Pyrrhocoris.

The method of labelling the fat body affects the distribution of label in the lipid classes in the fat body and in the released lipid. In all of the studies cited above the fat body was labelled by a brief, in vitro incubation in palmitate-1 $-{ }^{14} \mathrm{C}$ which may not allow the labelled fatty acid to be assimilated by the fat body in the pattern of normal lipid distribution. This was the case with $H$. cecropia fat body, in which there was three to five times as much label in the tissue DG as in TG, although TG accounts for 95 per cent of the fat body lipid while the proportion of DG is only 1.3 per cent (Chino and GilberT, 1965). Similarly, TiETz (1967) found that, after labelling the locust fat body by in vitro incubation, the specific activity of DG was 20 to 200 times greater than that of TG in the tissue. Furthermore, when the 
locust fat body was labelled over a 46 -hr period by injection of palmitate- ${ }^{14} \mathrm{C}$ into the haemocoel, the specific activities of DG and TG were equal. The distribution of label in Pyrrhocoris fat body, after feeding palmitate-1-14 C for several days, was very similar to the lipid class distribution in the fat body, i.e. predominantly in TG. Furthermore, labelling by in vitro incubation increased the proportion of released DG nearly threefold. It is suggested that the effect of in vitro labelling should be considered in measurements of lipid release.

\section{Haemolymph lipid}

Adult Pyrrhocoris females have the greatest concentration of lipid in their haemolymph (2.1 to $3.1 \%$ ) of any insect species reported (reviewed in WYaTT, 1961; Beenakkers, 1965; Chino and Gilbert, 1965; Nowosielski and Patton, 1965; SRIdHARA and Bhat, 1965; WlodaWer et al., 1966; Nelson et al., 1967). The high concentration of lipid in Pyrrhocoris haemolymph is correlated with the presence of large numbers of lipid-filled cells and lipid droplets in the haemolymph which are frequently so abundant that the haemolymph appears milky to the naked eye. These cells were termed adipoleucocytes by Hollande (1911), who found them to be present in Pyrrhocoris apterus and absent in all other insects examined ( 8 other species of Hemiptera, 5 Orthoptera, 2 Coleoptera, 3 Lepidoptera, and 5 Hymenoptera).

The lipid-filled cells (adipocytes) observed in the haemolymph of Pyrrhocoris look so much like fat body cells, and so unlike other blood cells, it is tempting and not unreasonable to postulate that they originated in the fat body. In a number of Diptera and Hymenoptera the fat body is reported to break down during metamorphosis, releasing its cells intact into the haemolymph (WIGGLESWORTH, 1965). SNODGRAss (1925) interpreted the detachment of cells from the honey bee fat body during metamorphosis as a mechanism for dissemination of storage products. The adipocytes of Pyrrhocoris may serve a similar transport function, but in contrast to the Diptera and Hymenoptera, the appearance of adipocytes is not limited to the immediate time of ecdysis; they are present in the fifth instar and throughout at least the first 5 days after adult ecdysis. Rhodnius has a type of blood cell ('lipocyte') which WIGGLESWORTH (1956) described as indistinguishable from small, detached fat body cells and originally (1933) described as homologous to the adipoleucocytes of Pyrrhocoris. Thus it appears that in some species and at certain stages the fat body releases its nutrient-packed cells into the haemolymph. It becomes important to know whether their contents provide a source of nutrition for other organs such as the ovary. Such a phenomenon has an apparent resemblance to holocrine secretion in mammals, through which entire cells die and their contents are then released. If the adipocytes eventually release their contents, it would be interesting to know whether they transfer their contents directly to recipient tissues or release them into the haemolymph, and what transformations occur in the lipid prior to uptake by other tissues.

Several results of the present in vitro study on release become understandable in light of the possibility that one way the Pyrrhocoris fat body makes its reserves 
available is by releasing entire cells. Assuming most of the released lipid is in cells or in droplets derived from cells, this phenomenon could explain why the released lipid is 90 per cent TG, a proportion similar to the composition of the intact fat body. Moreover, release of entire cells would contribute to the relatively constant composition of lipid, protein, and carbohydrate in the fat body which was observed during periods of considerable fluctuation in the amount of tissue, as described previously (MARTIN, 1969). In addition, increased agitation of a tissue which is undergoing a form of controlled disintegration could increase the rate of cell separation, which in this study would have yielded a loss of lipid from the tissue indistinguishable from release of lipid across the plasma membrane.

The term 'release' usually connotes passage across the plasma membrane. In this study, as in most other reported studies on the fat body, release was measured as the amount of labelled lipid appearing in the incubation medium. It must be borne in mind that at least some of the lipid 'released' from the fat body may never have crossed a membrane.

There is no reason to expect the Pyrrhocoris fat body to respond to a releasepromoting factor in the haemolymph in the same way as other species if the physiological process of lipid release is radically different in this species. However, it becomes all the more interesting to know how the release rate becomes so elevated on day 5 .

Correlation of data on in vitro uptake and release of lipid with changes observed in the fat body

The rate of lipid release, as measured in vitro, is essentially constant during the period of reversal from net storage to net mobilization of lipid (days 2, 3, and 4) and thus does not appear to contribute significantly to the alteration in lipid content of the fat body which occurs at this time. However, when the lipid concentration in the incubation medium was reduced by one-half, the rate of release increased threefold, a response consistent with a homeostatic mechanism acting to maintain a constant level of lipid in the haemolymph. The primary class of lipid released by Pyrrhocoris fat body is TG. The concentration of TG in the adult female haemolymph remains fairly constant during the first 5 days. Thus, the fat body may respond to changes in the haemolymph TG concentration by increasing release as the concentration drops and decreasing release when the concentration rises. This would contribute to the regulation of mobilization of fat body lipid to satisfy the needs of other organs.

The rate of uptake, on the other hand, does change at certain ages and is affected by the physiological state of the female and is therefore the most likely physiological parameter by which the amount of lipid in the fat body is regulated.

In order to determine whether the rates of release and uptake measured in vitro are physiologically meaningful, the calculated net change in lipid content of the fat body, which would be implicated by these data, was compared with the actual change in lipid content observed (MARTIN, 1969). This comparison was 
made for each of days $2,3,4$, and 5 , when the fat body undergoes an increase followed by a decrease in lipid content.

The calculated net change in fat body lipid over a 24-hr period compares favourably with the actually observed change in fat body lipid on days 2, 3, and 4 and in diapause (Table 14). The unusually high and unexplained release rate on day 5 is responsible for the large lipid reduction calculated from the in vitro data

TABle 14-Calculations and COMPARISON OF in vitro aNd in vivo LIPID CHANGE IN THE $P$. apterus FAT BODY

\begin{tabular}{|c|c|c|c|c|c|}
\hline Age & $\begin{array}{l}\text { Lipid uptake } \\
(\% / \mathrm{mg} \text { in } \\
30 \mathrm{~min})\end{array}$ & $\begin{array}{l}\text { Mean fat } \\
\text { body dry } \\
\text { wt. (mg)* }\end{array}$ & $\begin{array}{l}\text { Lipid uptake } \\
\text { (\%/fat body } \\
\text { in } 30 \mathrm{~min})\end{array}$ & $\begin{array}{c}\text { Total haemo- } \\
\text { lymph lipid } \\
(\mu \mathrm{g})\end{array}$ & $\begin{array}{c}\text { Uptake from } \\
\text { haemolymph } \\
(\mathrm{mg} / 24 \mathrm{hr})\end{array}$ \\
\hline Day 2 & $6 \cdot 4$ & $4 \cdot 7$ & $30 \cdot 1$ & $464 \cdot 0$ & $6 \cdot 71$ \\
\hline Day 3 & $5 \cdot 8$ & $7 \cdot 5$ & $43 \cdot 5$ & $567 \cdot 5$ & $11 \cdot 85$ \\
\hline Day 4 & $2 \cdot 6$ & $5 \cdot 7$ & $14 \cdot 8$ & $702 \cdot 5$ & 4.99 \\
\hline Day 5 & $3 \cdot 6$ & $4 \cdot 8$ & $17 \cdot 3$ & $686 \cdot 4$ & $5 \cdot 70$ \\
\hline Diapause & $3 \cdot 4$ & $6 \cdot 2$ & $21 \cdot 1$ & 715 & $7 \cdot 24$ \\
\hline Age & $\begin{array}{c}\% \text { Fat body } \\
\text { lipid } \\
\text { released } / \mathrm{hr}\end{array}$ & $\begin{array}{c}\text { Fat body } \\
\text { lipid } \\
(\mathrm{mg})^{*}\end{array}$ & $\begin{array}{c}\text { Lipid } \\
\text { released } \\
\text { from fat body } \\
(\mathrm{mg} / 24 \mathrm{hr})\end{array}$ & & \\
\hline $\begin{array}{l}\text { Day } 2 \\
\text { Day } 3 \\
\text { Day } 4 \\
\text { Day } 5\end{array}$ & $\begin{array}{r}5 \cdot 4 \\
6 \cdot 0 \\
5 \cdot 0 \\
15 \cdot 9\end{array}$ & $\begin{array}{l}3 \cdot 7 \\
6 \cdot 0 \\
4 \cdot 7 \\
3 \cdot 9\end{array}$ & $\begin{array}{r}4 \cdot 80 \\
8 \cdot 64 \\
5 \cdot 64 \\
14 \cdot 88\end{array}$ & & \\
\hline \multirow[t]{5}{*}{ Diapause } & 6.5 & $4 \cdot 5$ & $7 \cdot 03$ & & \\
\hline & \multicolumn{4}{|c|}{ 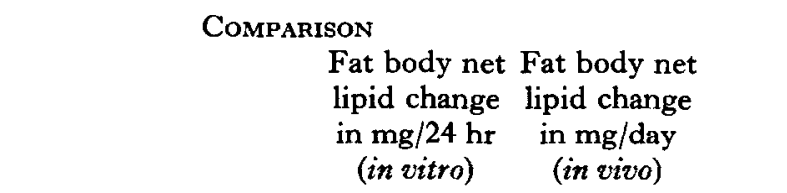 } & \\
\hline & \multicolumn{2}{|l|}{ Age } & alculated & bserved & \\
\hline & $\begin{array}{l}\text { Day } 2 \\
\text { Day } 3 \\
\text { Day } 4 \\
\text { Day } 5\end{array}$ & & $\begin{array}{l}+1 \cdot 9 \\
+3 \cdot 2 \\
-0 \cdot 7 \\
-9 \cdot 2\end{array}$ & $\begin{array}{l}+1 \cdot 2 \\
+2.3 \\
-1 \cdot 3 \\
-0.8\end{array}$ & \\
\hline & Diapau & & +0.2 & 0 & \\
\hline
\end{tabular}

+ , Net uptake; - , net loss.

* From Martin, 1968. 
for that day. During diapause the lipid content of the fat body hardly changes at all in a $24-\mathrm{hr}$ period and the calculated value was only $0.2 \mathrm{mg}$.

The calculations based on in vitro data include the assumption that the fat body did not oxidize or release a significant amount of incorporated label during the measurement of rate of uptake. Since the incubation lasted only $30 \mathrm{~min}$ and the rates of FFA oxidation and lipid release, under these conditions, are 1 per cent of the medium label/hr and 6.3 per cent of the tissue label/hr, respectively, error from these sources amounts to approximately 0.5 per cent of the label in the medium/mg of fat body, or approximately 11 per cent of the rate of uptake. Haemolymph volume was not measured in diapausing females; the value used is the average for active females.

\section{The relation of oöcyte production to the movement of lipid by the fat body}

There is good correlation between the observed lipid changes in the fat body and the rates of uptake and release of lipid measured in vitro. In addition, the metabolism of lipid to $\mathrm{CO}_{2}$ does not account for the observed changes in fat body lipid content. Therefore, it appears that control of lipid storage in the fat body occurs through alterations in the rate of lipid uptake. The primary alteration which occurs in rate of uptake is the precipitous drop on day 4 to less than half of the rate on day 3 (Table 8). This alteration is functionally related to the production of ova. The rate of uptake of day 4 females which had been ovariectomized remained at the level of days 2 and 3 females and did not drop to the value of normal day 4 females $(P=0.014)$ which were in the midst of rapid oöcyte growth.

On the basis of the results of this study, it is possible to explain the decrease in fat body mass (occurring during days 3 to 5 ) as being functionally dependent on oöcyte development and as involving two separate mechanisms. First, the ovary may contribute directly to the reduction in fat body reserves by withdrawing lipid from the haemolymph, thus effecting an increased rate of release from the fat body in response to the reduced lipid concentration in the haemolymph. Secondly, when the ovary begins its major growth, the rate of lipid uptake by the fat body decreases, contributing considerably to the net decrease in stored lipid. The means by which the rate of uptake is controlled are not presently clear. It is tempting to speculate that the effect of the ovary on uptake of lipid is attributable to some hormonal or other circulating factor. Since the characteristic rate of uptake persists for at least $30 \mathrm{~min}$ of incubation withour haemolymph, it appears that any circulating factor must have a persistent effect or a high affinity for the tissue.

Acknowledgements-The author is indebted to Dr. KAREL SLÁMA for provision of the original colonies of insects and for instruction on surgical procedures and maintenance of the insects. Discussions and helpful suggestions during the course of the research as well as critical reading of the manuscript by Dr. D. G. SHAPPIRIo are deeply appreciated. Advice on chemical procedures and loan of facilities by Dr. M. M. MARTIN are gratefully acknowledged. The research was done while the author was on a Public Health Service predoctoral fellowship and on National Institutes of Health Training Grant T1GM989. Some equipment was provided by Public Health Services Research Grant GM06101. 


\section{REFERENCES}

Amenta J. S. (1964) A rapid chemical method for quantification of lipids separated by thinlayer chromatography. F. Lipid Res. 5, 270-273.

Bally P. R., Cahill G. F. JR., Lebceuf B., and Renold A. E. (1960) Studies on rat adipose tissue in vitro- $\mathrm{V}$. Effects of glucose and insulin on the metabolism of palmitate1-14C. F. biol. Chem. 235, 333-336.

BEENAKkERS A. M. T. (1965) Transport of fatty acids in Locusta migratoria during sustained flight. F. Insect Physiol. 11, 879-888.

BeENAKKERS A. M. T. and GilberT L. I. (1968) The fatty acid composition of fat body and haemolymph lipids in Hyalophora cecropia and its relation to lipid release. F. Insect Physiol. 14, 481-494.

Bhakthan N. M. G. and Gilbert L. I. (1968) Effects of some vertebrate hormones on lipid mobilization in the insect fat body. Gen. comp. Endocr. 11, 186-197.

Bliss C. I. and Calmoun D. W. (1954) An Outline of Biometry. Yale Cooperative Corp., New Haven.

BORGSTRÖM B. (1952) Investigation on lipid separation methods. Separation of cholesterol esters, glycerides and free fatty acids. Acta physiol. scand. 25, 111-119.

BRAY G. A. (1960) A simple efficient liquid scintillator for counting aqueous solutions in a liquid scintillation counter. Analyt. Biochem. 1, 279-285.

Chino H. and Gilbert L. I. (1965) Lipid release and transport in insects. Biochim. biophys. Acta 98, 94-110.

Cook B. J. and Eddington L. C. (1967) The release of triglycerides and free fatty acids from the fat body of the cockroach, Periplaneta americana. F. Insect Physiol. 13, 13611372.

DOLE V. P. (1956) A relation between non-esterified fatty acids in plasma and the metabolism of glucose. $\mathcal{F}$. clin. Invest. 35, 150-154.

Folch J. M., Lees M., and Stanley G. H. (1957) A simple method for the isolation and purification of total lipids from animal tissues. F. biol. Chem. 226, 497-509.

FrenRickson D. S. and Gordon R. S., Jr. (1958) Transport of fatty acids. Physiol. Rev. 38, $585-630$.

FreEman C. P. and West D. (1966) Complete separation of lipid classes on a single thinlayer plate. \%. Lipid Res. 7, 324-327.

FrITZ I. B. and KAPLAN E. (1961) Effects of glucose on palmitate esterification by isolated rat diaphragms. Am. F. Physiol. 200, 1047-1050.

GILBERT L. I. (1967a) Changes in lipid content during the reproductive cycle of Leucophaea maderae and effects of the juvenile hormone on lipid metabolism in vitro. Comp. Biochem. Physiol. 21, 237-257.

GILBRRT L. I. (1967b) Lipid metabolism and function in insects. Adv. Insect Physiol. 4, 69-221.

Hollande A-CH. (1911) Étude histologique comparée du sang des insectes à hémorrhée et des insectes sans hémorrhée. Archs Zool. exp. gén. (5) 6, 283-323.

LEBCEUF B. (1965) Regulation of fatty acid esterification in adipose tissue incubated in vitro. Handbook of Physiology, Section 5, Adipose Tissue, pp. 385-391. American Physiological Society, Washington, D.C.

Martin J. S. (1968) Studies on the physiology of the fat body of Pyrrhocoris apterus L. Ph.D. Thesis, University of Michigan.

Martin J. S. (1969) Lipid composition of fat body and its contribution to the maturing oöcytes in Pyrrhocoris apterus. F. Insect Physiol. 15, 1025-1045.

Nelson D. R., Terranova A. C., and Sukkestad D. R. (1967) Fatty acid composition of the glyceride and free fatty acid fractions of the fat body and hemolymph of the cockroach, Periplaneta americana L. Comp. Biochem. Physiol. 20, 907-917. 
Nowosielski J. W. and PAtton R. L. (1965) Variation in the hemolymph protein, amino acid, and lipid levels in adult house crickets, Acheta domesticus L., of different ages. $\mathcal{F}$. Insect Physiol. 11, 263-270.

Robertson A. F. and Lands W. E. M. (1962) Positional specificities in phospholipid hydrolases. Biochemistry 1, 804-810.

Seifter S., Dayton S., Novic B., and Muntwyler E. (1950) The estimation of glycogen with the anthrone reagent. Archs Biochem. 25, 191-200.

Siakotos A. N. (1960) The conjugated plasma proteins of the American cockroach-I. The normal state. F. gen. Physiol. 43, 999-1013.

Sregel S. (1956) Nonparametric Statistics. McGraw-Hill, New York.

SLAMA K. (1964) Hormonal control of respiratory metabolism during growth, reproduction, and diapause in female adults of Pyrrhocoris apterus L. (Hemiptera). F. Insect Physiol. 10, 283-303.

SNodgrass R. E. (1925) Anatomy and Physiology of the Honeybee. McGraw-Hill, New York.

SNYDER F. and Strvens N. (1962) Quantitative C-14 and tritium assay of thin-layer chromatography plates. Analyt. Biochem. 4, 128-131.

SRIDHaRa S. and Bhat J. V. (1965) Lipid composition of the silkworm Bombyx mori L. F. Insect Physiol. 11, 449-462.

TrETZ A. (1962) Fat transport in the locust. F. Lipid Res. 3, 421-426.

TreTz A. (1967) Fat transport in the locust: The role of diglycerides. Europ. $\mathcal{F}$. Biochem. 2, 236-242.

Wigglesworth V. B. (1933) The physiology of the cuticle and of ecdysis in Rhodnius prolixus (Triatomidae, Hemiptera); with special reference to the function of the oenocytes and of the dermal glands. Quart. F. micr. Sci. 76, 269-318.

WiggleswORTH V. B. (1956) The haemocytes and connective tissue formation in an insect, Rhadnius prolixus (Hemiptera). Quart. F. micr. Sci. 97, 89-98.

Wigglesworth V. B. (1965) The Principles of Insect Physiology. Methuen, London.

Wlodawer P. and BARAŃska J. (1965) Lipolytic activity of the fat body of the waxmoth larvae-I. Fatty acid composition of the fat body and of the haemolymph lipids and release of free fatty acids from the fat body during incubation. Acta biochim. pol. 12, 23-37.

WLODAWER P. and LĄGWIŃSKA E. (1967) Uptake and release of lipids by the isolated fat body of the waxmoth larva. F. Insect Physiol. 13, 319-331.

WLODAWER P., LAGWTísKa E., and BARAŃSKa J. (1966) Esterification of fatty acids in the waxmoth haemolymph and its possible role in lipid transport. F. Insect Physiol. 12, $547-560$.

WYATT G. R. (1961) Lipid in hemolymph: Insects. In Blood and Other Body Fluids (Ed. by Altman P. L.), p. 286. Federation of American Societies for Experimental Biology, Washington, D.C. 